\title{
Hubungan Faktor Individu dan Lingkungan dengan Perilaku Menyalahgunakan Napza di Lembaga Pemasyarakatan Kelas II.a Pekanbaru
}

\author{
Usraleli $^{1 *}$, Novy Helena ${ }^{2}$, Basmanelly ${ }^{3}$ \\ ${ }^{1}$ Mahasiswa S2 Keperawatan Universitas Andalas \\ ${ }^{2}$ Dosen Pengajar Fakultas Ilmu Keperawatan Universitas Indonesia \\ ${ }^{3}$ Perawat RSJ Prof HB Saanin Padang \\ *Correspondence email: usraleli@pkr.ac.id
}

\begin{abstract}
Abstrak. Tahun 2015 kasus NAPZA di Riau diperkirakan akan meningkat tajam dibandingkan 2014 karena letak geografisnya dikelilingi lautan sehingga memiliki pantai yang mudah menjadi tempat lalu lintas peredaran NAPZA. Faktor individu yang menyebabkan penyalahgunaan NAPZA adalah keingintahuan, keinginan diterima kelompok, mengikuti kecenderungan, mencari kenikmatan, mencari perhatian dan meniru orang terkenal. Sedangkan faktor lingkungan adalah hubungan keluarga tidak harmonis, hubungan interpersonal yang buruk, orang tua/anggota keluarga juga pengguna, masyarakat kurang peduli, kurang kontrol sosial dan tekanan kelompok. Tujuan penelitian ini adalah mengidentifikasi hubungan faktor individu dan lingkungan dengan perilaku menyalahgunakan NAPZA di Lapas kelas II A Pekanbaru. Penelitian ini dilaksanakan mulai Maret sampai dengan Agustus 2015 dengan desain analitik cross secsional pada 89 orang warga binaan. Hasil penelitian menunjukkan semua faktor individu dan lingkungan mempunyai hubungan dengan perilaku menyalahgunakan NAPZA kecuali sub variabel lingkungan yaitu orang tua/anggota keluarga juga pengguna. Kontribusi faktor Individu dalam perilaku menyalahgunakan NAPZA memperlihatkan dari 6 faktor individu yang paling menonjol adalah rata-rata keingintahuan warga binaan adalah sebesar 75,78 $\pm 15,987$ (hasil terendah 25 dan tertinggi 100) dan yang paling kurang adalah rata-rata keinginan mencari perhatian dalam menyalahgunakan NAPZA adalah 52,83 $\pm 18,018$ (hasil terendah 8 dan tertinggi 100 Hasil penelitian ini dapat dijadikan sebagai bahan kegiatan pembinaan terkait faktor individu dan lingkungan di Lapas.
\end{abstract}

Kata kunci: Faktor individu; lingkungan warga binaan; perilaku menyalahgunakan NAPZA

Abstract. In 2015 the NAPZA case in Riau expected to increase sharply compared to 2014 due to its geographical location that surrounded by the ocean that it had a beach which was easy for a place for drug traffic. Individual factors that cause drug abuse were curiosity, desires to be accepted by the group, following tendencies, seeking pleasure, seeking attention and imitating famous people. Whereas environmental factors were from family relations who were not harmonious, poor interpersonal relationships, parents/family members were also drug users, the communities are less concerned, lack social control and group pressure. The purpose of this study is to identify the relationship between individual factors and the environment with drug abuse in class II A prisons in Pekanbaru. This research was conducted from March to August 2015 with a cross-sectional analytic design on 89 assisted residents. The results showed that all individual and environmental factors had a relationship with drug abuse behaviour except for the environmental sub-variables, namely parents/family members as well as users. The contribution of Individual factors in drug abuse indicated that of the six most prominent individual factors are the average curiosity of the inmates is $75.78 \pm 15.987$ (the lowest results are 25 , and the highest is 100 . The least was the common desire to seek attention in abusing NAPZA is $52.83 \pm 18.018$ (the lowest results are 8 , and the highest is 100. The results of this study could use as material for coaching activities related to individual and environmental factors in prison.

Keywords: Individual factors; the environment of fostered citizens; drug abuse behaviour

\section{PENDAHULUAN}

Hasil survei National Institute for Mental Health (NIMH) di Amerika Serikat menyebutkan 14\% populasi orang dewasa mengalami gangguan alkohol dan $6,2 \%$ mengalami gangguan zat selain alkohol atau tembakau. Hasil survei Substance Abuse and Menthal Health Services Administration menyebutkan anak usia 12-17 tahun 9\% menggunakan zat terlarang dan 18,8\% mengkonsumsi alkohol dalam sebulan (Videbeck, 2008). Menurut penelitian BNN, Pusdiklat UI dan berbagai universitas negeri terkemuka tahun 2005 prevalensi penyalahgunaan NAPZA ialah $1,75 \%$ dari jumlah penduduk di Indonesia, tahun 2008 naik menjadi 1,88\%, tahun 2011menjadi 2,2\% dan tahun 2012 naik kembali menjadi 2,8\% ( setara dengan 5,8 juta penduduk). Faktanya pengguna NAPZA semakin banyak, bahkan ke aparat pemerintah dan penegak hukum (BNN RI, 2012). Prevalensi zat yang paling banyak disalahgunakan dalam lima tahun terakhir ialah shabu sebanyak 11.247 orang, kategori umur tertinggi ialah > 29 tahun sebanyak 17.585 orang, jenis kelamin terbanyak ialah laki-laki sebesar 90,80\%, latar belakang pendidikan terbanyak ialah SLTA, pekerja swasta ialah jenis pekerjaan tertinggi penyalahguna NAPZA dan status perkawinan yang tertinggi ialah belum menikah sebanyak 57\% 
(Buletin Data dan Informasi Kesehatan Kemenkes RI, Semester I, Juli 2014).

Menurut data BNN dan Polri (2013) jumlah kasus NAPZA di Riau tahun 2010 sebanyak 677 kasus lalu meningkat menjadi 855 kasus pada tahun 2012 kemudian meningkat lagi menjadi 980 kasus). Tahun 2015 kasus NAPZA Riau diperkirakan akan meningkat tajam dibandingkan 2014. Terjadinya peningkatan kasus NAPZA di Provinsi Riau karena letak letak geografis Provinsi Riau yang dikelilingi lautan, sehingga memiliki pantai yang mudah menjadi tempat lalu lintas peredaran narkotika, psikotropika dan zat terlarang. Pemakaian NAPZA ini disebabkan oleh beberapa faktor yang saling berkaitan dan dapat terjadi bersamaan.

\section{METODE}

Penelitian ini menggunakan pendekatan cross sectional, yang bertujuan untuk mendapatkan gambaran tentang hubungan faktor individu dan lingkungan dengan perilaku menyalahgunakan NAPZA. Peneliti menggunakan desain cross sectional yaitu desain penelitian yang mencari hubungan antara variabel bebas dengan variabel tergantung dengan melakukan pengukuran pada suatu saat (Notoatmodjo, 2010; Sastroasmoro \& Ismael, 2011). Desain penelitian cross sectional digunakan karena pengumpulan data terkait dengan variabel dependen dan variabel independen dilakukan dalam waktu bersamaan dengan cara membagikan kuesioner kepada warga binaan yang ada. Penelitian ini telah dilakukan di Blok D Lembaga Pemasyarakatan Kelas II A Pekanbaru Riau. Penelitian ini telah dilaksanakan pada bulan Maret sampai dengan Agustus 2015.

Populasi pada penelitian ini adalah seluruh warga binaan Lembaga Pemasyarakatan Kelas II A Pekanbaru Riau dengan kasus NAPZAsebanyak 898 orang. Populasi pada penelitian ini adalah seluruh warga binaan Lembaga Pemasyarakatan Kelas II A Pekanbaru Riau dengan kasus NAPZAsebanyak 898 orang. Setelah jumlah warga binaan ditentukan, selanjutnya peneliti menentukan dari blok mana sampel diambil. Lembaga Pemasyarakatan Kelas II A Pekanbaru memiliki 7 blok yaitu blok Anggrek, Bougenvile, Cemara, Dahlia, Edelweis, Flamboyan dan Tipikor. Dari ketujuh blok tersebut hanya blok Dahlia saja yang semua kasusnya NAPZA sedangkan blok yang lain merupakan perpaduan antara kasus narkotika, ilegal loging, korupsi, traficking, perjudian dan terorisme. Berdasarkan pertimbangan dan arahan Kepala Pengamanan Lembaga Pemasyarakatan (KPLP) maka sampel yang peneliti ambil adalah dari blok D yang terdiri dari 10 kamar dan masing-masing kamar dihuni oleh 30 orang. Langkah berikutnya adalah cara mengambil 89 sampel dari 10 kamar tersebut dengan cara tehnik random sederhana (simple random sampling) dengan cara mengundi (lotre) kamar 1 sampai kamar 7 diambil masing-masing kamar sebanyak 9 orang dan kamar 8 sampai dengan kamar 10 masingnya 8 orang ( 7 kamar $\times 9$ orang $=63$ sampel ; 3 kamar $\mathrm{x} 8$ orang $=24$ sampel).Supaya hasil penelitian sesuai dengan kriteria yang diinginkan peneliti, maka dibuat kriteria tertentu. Kriteria sampel dapat berupa kriteria inklusi dan kriteria ekslusi. Kriteria inklusi adalah kriteria yang harus dimiliki oleh individu dalam populasi untuk dapat dijadikan sampel dalam penelitian, sedangkan kriteria eksklusi adalah kriteria yang tidak boleh ada atau tidak boleh dimiliki oleh sampel yang akan digunakan untuk peneliti karena dapat mempengaruhi hasil penelitian sehingga terjadi bias (Saryono dan Anggraini, 2013).

\section{Adapun kriteria inklusi untuk penelitian ini adalah:}

1. Berusia 21-50 tahun

2. Dapat membaca dan menulis

3. Secara sukarela bersedia sebagai responden

\section{Adapun kriteria ekslusi untuk Penelitian ini adalah:}

1. Sedang menjalani sakit serius

2. Warga Binaan Pemasyarakatan dengan penyakit HIV/AIDS.

Alat ukur yang digunakan untuk memperoleh data dalam penelitian ini adalah dengan menggunakan kuisioner yang diisi sendiri. Kuisioner adalah alat pengumpul data penelitian dirumuskan dengan kriteria tertentu (Danim,2003).Instrument atau alat pengumpulan data yang digunakan oleh peneliti adalah instrument atau alat pengumpulan data yang peneliti modifikasi dari hasil penelitian yang dilakukan oleh Roseline (2010) dengan judul hubungan faktor individu dan lingkungan dengan perilaku penggunaanpada remaja di Balai Pemulihan Sosial Pamardhi Putra Lembang Bandung. Uji Validitas dilakukan di blok lain selain blok Dahlia pada 30 orang. Uji validitas dilakukan dengan menggunakan Pearson Product Moment (r) yaitu : membandingkan antara skor nilai setiap item pertanyaan dengan skor total kuisioner.

\section{Pengumpulan data dilakukan dengan cara:}

mengajukan surat ijin penelitian dari Fakultas Keperawatan Unand lalu dilanjutkan dengan ijin dari Kementerian Hukum dan Hak Azazi Manusia Republik Indonesia untuk dilanjutkan ke Lembaga Pemasyarakatan Kelas II A Pekanbaru. Berdasarkan pertimbangan dan arahan Kepala Pengamanan Lembaga Pemasyarakatan (KPLP) maka peneliti hanya diizinkan menyebar kuesioner pada warga binaan dari blok Dahlia.Warga binaan dikumpulkan di ruangan Registrasi sebanyak 6 orang /1x sesi penyebaran kuesioner. Untuk mempercepat waktu, maka peneliti meminta bantuan 2 orang enumerator dari sipir Lapas 


\section{HASIL DAN PEMBAHASAN}

Berdasarkan faktor Individu dalam Perilaku Menyalahgunakan NAPZA di Lembaga Pemasyarakatan Kelas II A Pekanbaru Tahun 2015memperlihatkan dari 6 faktor individu yang paling menonjol adalah rata-rata keingintahuan warga binaan dalam menyalahgunakan narkotika, psikotropika dan zat terlarang adalah sebesar $75,78 \pm 15,987$ (hasil terendah 25 dan tertinggi 100) dan yang paling kurang adalah rata-rata keinginan mencari perhatian dalam menyalahgunakan NAPZA adalah $52,83 \pm 18,018$ (hasil terendah 8 dan tertinggi 100).Berdasarkan hasil uji Mann-Whitney diperoleh bahwa dari ketiga faktor individu, semua nilai $\mathrm{p}$ adalah 0,000 berarti ada hubungan yang signifikan secara statistik antara keingintahuan, mencari kenikmatan dan meniru orang lain dengan perilaku menyalahgunakan NAPZA.Dari ketiga faktor individu yang paling menonjol adalah keinginan diterima kelompok dengan rata-rata pada kelompok kecanduan sebesar 73,48 $\pm 8,418$ dan ketergantungan sebesar 56,19 $\pm 20,352$. Ketiga nilai $p$ yang diperoleh adalah 0,000 berarti ada hubungan yang signifikan secara statistik antara keinginan diterima kelompok, mengikuti kecenderungan dan mencari perhatian dengan perilaku menyalahgunakan NAPZA.

Berdasarkan faktor lingkungan dalam perilaku menyalahgunakan NAPZAdi Lembaga Pemasyarakatan Kelas II A Pekanbaru Tahun 2015 memperlihatkan dari 6 faktor lingkungan yang paling menonjol adalah ratarata keluarga tidak harmonis yang menyebabkan warga binaan menyalahgunakan NAPZA sebesar 50,56 $\pm 32,311$ (hasil terendah 0 dan tertinggi 100) dan paling kurang adalah rata-rata orangtua/anggota keluarga juga pengguna menyebabkan warga binaan menyalahgunakan NAPZA sebesar 25,73 $\pm 24,858$ (hasil terendah 0 dan tertinggi 100).

Hasil uji t Independen pada faktor lingkungn diperoleh rata-rata dari kedua faktor lingkungan yang paling menonjol adalah pada kelompok kecanduan sebesar 54,65 $\pm 17,106$. Yang paling menonjol dari faktor lingkungan adalah keluarga tidak harmonis pada kelompok kecanduan sebesar 68,95 \pm 19,336 dan ketergantungan sebesar17,81 $\pm 23,655$. Kedua nilai $p$ adalah 0,000 yang berarti ada hubungan yang signifikan secara statistik antara keluarga tidak harmonis dan kurang kontrol sosial dengan perilaku menyalahgunakan NAPZA.

Awalnya ada tekanan norma-norma dan harapan kelompok namun seiring menuju kedewasaan tekanan sebelumnya mulai terkikis. Menurut Hudock (2000) seseorang yang diterima teman sebaya berarti dipilih sebagai teman untuk suatu aktifitas dalam kelompoknya. Catio (2006) mengatakan kelompok dibentuk karena adanya kesamaan hobi, memiliki kecocokan satu sama lain dan wadah saling berbagi. Kebutuhan akan kelompok sebaya semakin diperlukan dalam kehidupannya apabila merasa sendiri. Adanya perasaan terisolir dan ingin dapat diterima merupakan alasan penyalahgunaan narkotika, psikotropika dan zat terlarang (Explan, 2005). Berteman dengan pengguna menimbulkan risiko 46 kali menjadi pengguna zatdibandingkan dengan berteman tidak pengguna.Individu mengenal dan mendapatkan narkotika, psikotropika dan zat terlarang dari teman sedangkan pada kelompok umur yang lebih muda (13-16 tahun) risiko yang paling berpengaruh menyalahgunakan zat adalah keluarga.

\section{SIMPULAN}

Perilaku menyalahgunakan NAPZA di Lembaga Pemasyarakatan Kelas II A Pekanbaru lebih dari separuh termasuk kategori kecanduan.Faktor individu yang paling menonjol terhadap perilaku menyalahgunakan NAPZA di Lembaga Pemasyarakatan Kelas II A Pekanbaru adalah keingintahuan. Faktor lingkungan yang paling menonjol terhadap perilaku menyalahgunakan NAPZA di Lembaga Pemasyarakatan Kelas II A Pekanbaru adalah keluarga tidak harmonis. Semua faktor individu mempunyai hubungan yang signifikan dengan perilaku menyalahgunakan NAPZA di Lembaga Pemasyarakatan Kelas II A Pekanbaru. Semua faktor lingkungan mempunyai hubungan yang signifikan dengan perilaku menyalahgunakan NAPZA di Lembaga Pemasyarakatan Kelas II A Pekanbaru kecuali keluarga/anggota keluarga juga pengguna.

Berdasarkan hasil penelitian rata-rata umur warga binaan di Lembaga Pemasyarakatan kelas II A Pekanbaru adalah 27,83 tahun (95\% CI : 26,59 - 29,08), dengan standar deviasi adalah 5,917 tahun yang merupakan usia produktif. Hasil penelitian ini sejalan dengan penelitian Sartika (2010), Windiarti (2013) dan Djamaluddin (2014) yang semua usianya $<30$ tahun. Penelitian Sartika (2010) mengatakan rata-rata usia klien yang menjalani terapi relapse prevention training di DKI adalah 28,75 tahun. Penelitian Windiarti (2013) tentang pengaruh terapi stop berfikir negatif terhadap ketergantungan narkoba di Panti Rehabilitasi Narkoba di Rumah Damai Gunung Pati Semarang yang mengatakan $56,7 \%$ penderita ketergantungan narkoba dari kelompok umur 20-30 tahun. Penelitian Rustyawati (2010) yang menyebutkan $72 \%$ umur korban penyalahguna narkoba yang menjalani terapi di Semarang adalah 21-30 tahun.Penggunaan zat umumnya dimulai sejak awal remaja, kemudian puncaknya pada awal usia adolesen, lalu menurun tergantung pada zat yang digunakan. Tetapi sebagian individu melanjutkan penggunaannya sampai akhir dasawarsa ketiga kehidupan (Nurdin, 2007).

Berdasarkan hasil penelitian menunjukkan keinginan diterima kelompok pada warga binaan yang kecanduan adalah 73,48 $\pm 8,418$ dan yang ketergantungan adalah $56,19 \pm 20,352$. Nilai $p$ yang diperoleh adalah 0,000 yang berarti ada hubungan yang signifikan secara 
statistik antara keinginan diterima kelompok dengan perilaku menyalahgunakan narkotika, psikotropika dan zat terlarang Penelitian ini sejalan dengan penelitian Soetjiningsih (2004) dan Rustyawati (2010). Penelitian Rustyawati (2010) yang mengatakan 97,4\% memiliki teman sebaya penyalahguna zat.

\section{Ucapan Terima Kasih}

Penulis menyampaikan ucapan terima kasih kepada jajaran manajemen Poltekkes Kemenkes Riau, Kepala Lembaga Pemasyarakatan Kelas IIA Pekanbaru, Dekan Fakultas Ilmu Keperawatan, Ketua Prodi Magister Keperawatan Universitas Andalas Padang, pembimbing 1 dan 2, Penguji 1, 2 dan 3 sertaRekanrekan Angkatan 2013Pendidikan Program Studi Magister Keperawatan Peminatan Keperawatan Jiwa Universitas Andalas.

Berdasarkan hasil penelitian warga binaan yang mengikuti kecenderungan pada kelompok kecandungan adalah 65,05 $\pm 11,091$ dan kelompok ketergantungan $51,81 \pm 17,902$. Nilai $p$ adalah 0,000 yang berarti ada hubungan yang signifikan secara statistik antara mengikuti kecenderungan dengan perilaku menyalahgunakan narkotika, psikotropika dan zat terlarang. Penelitian ini sejalan dengan penelitian Roseline (2010) yang menemukan $45 \%$ remaja di Balai pemulihan sosial Pamardhi Putra Lembang Bandung menyalahgunakan zat karena mengikuti kecenderungan.

Catio (2006) mengatakan ikatan pergaulan yang kental dengan teman pemakai narkotika, psikotropika dan zat terlarang dan frekuensi pertemuan yang sering saat menggunakan NAPZA memungkinkan seseorang termotivasi untuk mengulang kembali, meskipun telah diketahui bahkan telah merasakan efek yang tidak menyenangkan. Martono dan Joewana (2006) mengatakan penggunaan narkotika, psikotropika dan zat terlarang merupakan tanggapan akan pengaruh sosial, media massa menggambarkan kebutuhan orang yang merasa high sebagai bagian gaya hidup dan atau seorang meniru trend apa yang sedang in saat itu.

\section{DAFTAR PUSTAKA}

BNN RI. (2009). Advokasi pencegahan penyalahgunaan narkoba. Diambil dari http: kampungbenar.wordpress.com/pemicu-terjadinyapenyalahgunaan-narkoba/. Tanggal 10 April 2015

Buletin Data dan Informasi Kesehatan Kemenkes RI, Semester I, Juli 2014.

Catio, M. (2006), Pencegahan dan penanggulangan penyelahgunaan narkoba, Jakarta

Joewana, S. (2005). Gangguan mental dan perilaku akibat penggunaan zat psikoaktif: penyalahgunaan NAPZA/Narkoba (edisi 2), . Jakarta: EGC

Martono, L.H \& Joewana, S. (2006). Masa remaja cenderung rawan menggunakan narkoba. Sadar
Aware \& Care, Majalah bulanan narkotika nasional. 08 (IV), 34-37

Nurdin, A.E (2007).Mada sejarah, dampak klinis dan penanggulangannyat, Semarang ; Mutiara Wacana

Nurdin, A.E (2011).Tumbuh kembang perilaku manusia, Jakarta ; EGC

Nurdin, A.E (2011). Keluarga dan penyalahguna zat psikoaktif endemik sumatera, Padang

Roseline, T. (2010). Hubungan faktor individu dan lingkungan dengan perilaku penggunaan NAPZA pada remaja di balai pemulihan sosial pamardhi putra Lembang Bandung, Jakarta : FK UI

Rustyawati. (2010), Beberapa faktor resiko yang berhubungan dengan penyalahguna narkoba pada penderita yang dirawat dipanti rehabiitasi, Semarang

Sabri, L \& Hastono, S.P. (2010) . Statistik kesehatan. Jakarta; PT Raja Grafindo Persada.

Santrock J.W (2007). Remaja. (Edisi 11 jilid 2), Jakarta : Penerbit Erlangga

Sartika, D (2010). Pengaruh relapse prevention training terhadap kekambuhan dan kepatuhan klien ketergantungan heroin yang menjalani program terapirumatan metadon di DKI. Jakarta : FK UI

Sastroasmoro, S. \& Ismail, S (2008). Dasar-dasar metodologi penelitian klinis, $\left(3^{\text {th }}\right.$ ed), Jakarta ; CV Sagung Seto

Videbeck, S. (2008). Buku ajar keperawatan jiwa. Jakarta.EGC 